Mizan; Jurnal IImu Syariah, FAI Universitas Ibn Khaldun (UIKA) BOGOR

Vol. 2 No. 1 (2014), pp. 47-56, link: https://www.academia.edu/13394292

\title{
Pembagian Harta Waris Dengan Wasiat (Pendekatan Ushul Fiqih)
}

\section{(A HIDDEN INHERITANCE WITH THE PROBATE DIVISION; USUL FIQH APPROACH)}

\author{
Arip Purkon \\ Fakultas Syariah dan Hukum UIN Jakarta \\ Jl. Ir. H. Juanda No.95 Ciputat Tangsel \\ Email: arippurkon@gmail.com
}

\begin{abstract}
In Islamic law, the division of the estate (faraidh) is part of the problem is already clear rules (qat'i al-dilalah). However, there are still a few people who questioned aspects of justice in this faraidh problem. One solution to bridge this is the concept of testament. The division of property by testamentary relatively more flexible than those specified in the science faraidh. However, will still not be separated from the legal rules that have been set Qur'an and Sunnah.
\end{abstract}

Keywords: Waris, Probate, Sunday, Mutawatir

\begin{abstract}
Abstrak: Dalam hukum Islam, pembagian harta waris (faraidh) merupakan bagian dari masalah yang sudah jelas aturannya (qat'i al-dilalah). Walaupun begitu, masih ada segelintir orang yang mempermasalahkan aspek keadilan dalam masalah faraidh ini. Salah satu solusi untuk menjembatani hal ini adalah adanya konsep wasiat. Pembagian harta berdasarkan wasiat relatif lebih fleksibel daripada yang telah ditentukan dalam ilmu faraidh. Walaupun demikian, wasiat tetap tidak terlepas dari aturan-aturan legal yang telah ditetapkan Alquran dan sunnah.
\end{abstract}

Kata Kunci: Waris, Wasiat, Ahad, Mutawatir

${ }^{*}$ Diterima tanggal naskah diterima: 30 April 2014, direvisi: 12 Mei 2014, disetujui untuk terbit: 30 Mei 2014. 


\section{Pendahuluan}

Masalah pembagian waris merupakan salah satu masalah yang senantiasa menjadi objek pembicaraan di kalangan umat Islam. Hal ini disebabkan antara lain karena pembagian warisan merupakan masalah yang langsung bersentuhan dengan praktek kehidupan. Selain itu, hukum waris versi Islam selalu mendapat kritikan terutama dari aktifis kesetaraan jender. Padahal para fuqaha (ahli hukum Islam) telah menetapkan bahwa ayat-ayat Alquran yang menjelaskan tentang bagian-bagian ahli waris merupakan ayat yang qath'i al-dilalah (penunjukkan hukumnya sudah pasti), sehingga tidak membuka peluang untuk berijtihad di dalamnya.

Dalam situasi tertentu, ada hal-hal yang dianggap kurang adil, menurut segelintir orang, dalam pembagian waris ini. Misalnya seorang anak laki-laki, yang dalam kebanyakan budaya masyarakat selalu mendapat pendidikan yang lebih tinggi dari anak perempuan. Akan tetapi ketika pembagian waris, anak laki-laki ini justru mendapat dua kali bagian anak perempuan. Sebenarnya ada satu cara untuk menyelesaikan hal ini yaitu dengan wasiat. Akan tetapi, konsep wasiat yang selama ini dipahami adalah bahwa wasiat tersebut tidak boleh melebihi 1/3 dari harta peninggalan. Dan apabila wasiat tersebut ditujukan untuk ahli waris, maka harus mendapat persetujuan dari ahli waris yang lainnya. Di sinilah timbul permasalahan lain.

Tulisan ini akan membahas masalah pembagian harta waris berdasarkan wasiat ditinjau dari perspektif ushul fiqh dan filsafat hukum Islam. Dengan menggunakan dua perspektif ini, kesimpulan yang dihasilkan diharapkan mempunyai landasan dalil dan metodologi yang dapat dipertanggungjawabkan.

\section{Urgensi Wasiat Dalam Kewarisan}

Wasiat secara etimologi adalah pesan atau janji seseorang kepada orang lain untuk melakukan suatu perbuatan, baik ketika orang yang berwasiat masih hidup maupun setelah wafat. ${ }^{1}$ Wasiat merupakan salah satu bentuk sarana tolong-menolong antara sesama muslim baik yang bersifat materi maupun manfaat.

${ }^{1}$ Wahbah al-Zuhaili, Al-Figh al-Islami wa Adillatuhu, (Beirut: Daar al-Fikr, 2004), jilid 10, hlm. 7440-7441. 
Sedangkan secara terminologi, para ulama fiqh mendefinisikan wasiat sebagai penyerahan harta secara suka rela dari seseorang kepada pihak lain yang berlaku setelah orang tersebut wafat, baik harta itu berbentuk materi maupun berbentuk manfaat. ${ }^{2}$ Dari definisi ini terlihat perbedaan antara wasiat dan pemilikan harta lainnya seperti jual beli atau sewa menyewa, karena pemilikan dalam kedua bentuk akad yang terakhir ini bisa berlaku semasa yang bersangkutan masih hidup. Sedangkan wasiat, sekalipun akadnya dibuat ketika orang yang berwasiat masih hidup, tetapi hukumnya baru berlaku setelah orang yang berwasiat itu wafat. Sebelum itu, akad wasiat tersebut tidak mempunyai efek apapun dari segi perpindahan hak milik kepada orang yang diberi wasiat.

Adapun masalah pembagian harta warisan dalam Islam telah diatur dalam ilmu faraid yaitu ilmu yang berkaitan dengan harta peninggalan, cara menghitung pembagiannya serta bagian masing-masing ahli waris. ${ }^{3}$ Namun terkadang dalam masalah-masalah yang bersifat kasuistik, pembagian waris berdasarkan faraid ini menimbulkan beberapa pertanyaan. Seperti adanya kerabat dekat yang miskin tapi tidak termasuk dalam ashhab al-furudh, atau ashhab al-furudhnya termasuk orang-orang yang kaya. Dalam kasus-kasus seperti ini, maka perlu ada solusi, yang salah satunya adalah dengan wasiat orang yang meninggal. Berdasarkan atas pertimbangan kemaslahatan, seseorang dapat berwasiat tentang pembagian seluruh hartanya. Akan tetapi hal ini bukan berarti tidak mempercayai masalah konsep pembagian waris dalam Islam, tetapi justru berusaha untuk menempatkan konsep pembagian waris ini secara proporsional, sebagaimana Umar bin Khatab RA yang tidak melakukan hukuman potong tangan terhadap pencuri karena adanya pertimbangan yang bersifat kasuistik.

\section{Tinjauan Ushul Fiqh Terhadap Pembagian Harta Waris dengan Wasiat}

Berkenaan dengan wasiat untuk pembagian harta waris ada beberapa ayat Alquran dan hadits yang perlu diperhatikan sebagai landasan normatif. Landasan normatif ayat Alquran dapat ditemukan antara lain dalam surat alBaqarah ayat 180:

2 Wahbah al-Zuhaili, Al-Figh al-Islami wa Adillatuhu, hlm. 7440-7441.
${ }^{3}$ Wahbah al-Zuhaili, Al-Figh al-Islami wa Adillatuhu, hlm. 7697. 


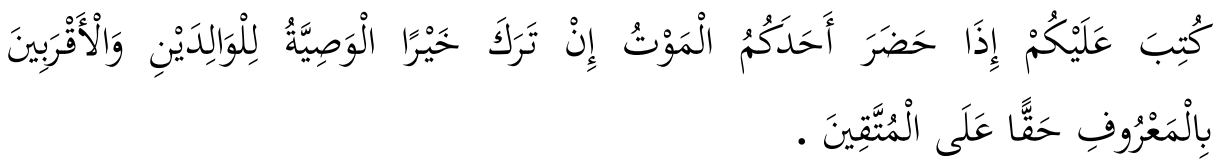

“Diwajibkan atas kamu, apabila seorang di antara kamu kedatangan (tandatanda) maut, jika ia meninggalkan harta yang banyak, berwasiat untuk ibubapak dan karib kerabatnya secara ma`ruf, (ini adalah) kewajiban atas orangorang yang bertakwa."

Ayat di atas mewajibkan kepada orang-orang yang menyadari kedatangan tanda-tanda kematian agar memberi wasiat kepada orang-orang yang ditinggalkan berkaitan dengan hartanya, bila harta tersebut banyak.

Begitu juga dalam surat al-Nisa ayat 11:

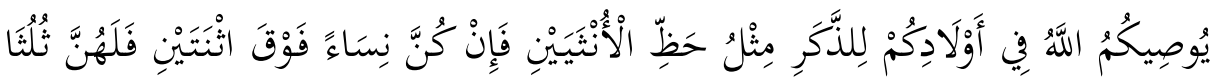

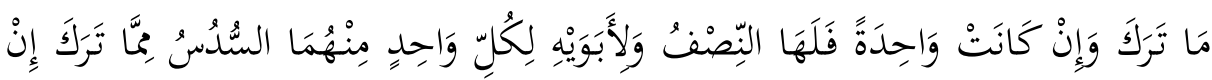

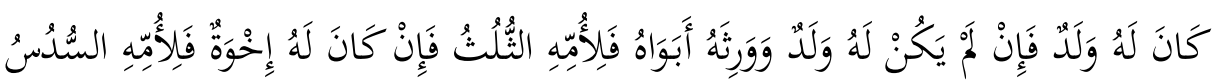

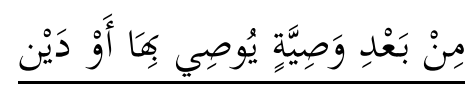

“Allah mensyari 'atkan bagimu tentang (pembagian pusaka untuk) anakanakmu. Yaitu: bahagian seorang anak lelaki sama dengan bahagian dua orang anak perempuan; dan jika anak itu semuanya perempuan lebih dari dua, maka bagi mereka dua pertiga dari harta yang ditinggalkan; jika anak perempuan itu seorang saja, maka ia memperoleh separo harta. Dan untuk dua orang ibu-bapak, bagi masing-masingnya seperenam dari harta yang ditinggalkan, jika yang meninggal itu mempunyai anak; jika orang yang meninggal tidak mempunyai anak dan ia diwarisi oleh ibu-bapaknya (saja), maka ibunya mendapat sepertiga; jika yang meninggal itu mempunyai beberapa saudara, maka ibunya mendapat seperenam. (Pembagianpembagian tersebut di atas) sesudah dipenuhi wasiat yang ia buat atau (dan) sesudah dibayar hutangnya".

Dari ayat ini dapat disimpulkan bahwa pembagian waris dilakukan setelah wasiat orang yang meninggal dilaksanakan serta semua hutangnya sudah dibayar. Penyebutan wasiat didahulukan atas penyebutan hutang, walaupun dalam pelaksanaannya yang paling utama diselesaikan adalah hutang, sehingga jika harta yang ditinggalkan hanya cukup untuk membayar hutang, maka siapapun keluarga yang ditinggalkan tidak akan memperoleh sesuatu. Didahulukannya kata wasiat di sini adalah untuk menunjukkan 
betapa penting berwasiat, dan untuk mengingatkan para ahli waris agar memperhatikannya, karena tidak mustahil mereka mengabaikan wasiat atau menyembunyikannya. Berbeda dengan hutang yang sulit disembunyikan karena pasti yang memberi hutang akan menuntut. ${ }^{4}$

Adapun dalam sebuah hadit diriwayatkan bahwa Sa'ad bin Abi Waqas RA bermaksud untuk berwasiat menshadaqahkan seluruh hartanya padahal dia mempunyai seorang anak perempuan. Lalu Rasulullah Saw. mengatakan tidak boleh. Sa'ad bin Abi Waqas lalu menurunkan jumlah harta yang akan dishadaqahkannya sampai sepertiga hartanya. Maka Rasulullah Saw. menjawab :

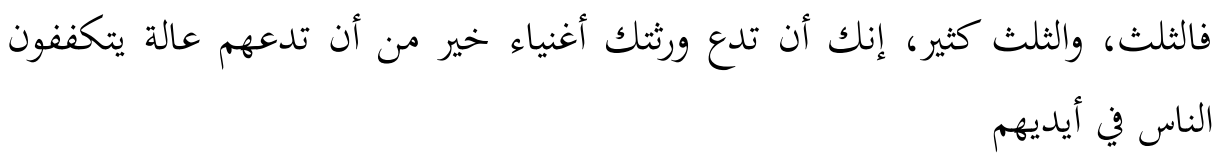

"Sepertiga (untuk shadaqah/wasiat), dan sepertiga itu banyak, karena kamu meninggalkan ahli waris dalam keadaan kaya lebih baik dari pada meninggalkan mereka miskin serta menjadi beban orang lain." ${ }^{5}$

Hadits ini menjadi dalil bahwa wasiat tidak boleh lebih dari sepertiga harta peninggalan kalau ada ahli waris. Adapun kalau tidak ada ahli waris, maka boleh berwasiat dengan seluruh harta peninggalan. Alasan (illat) hukum dari masalah ini adalah untuk menjaga agar ahli waris tidak jatuh dalam kemiskinan. ${ }^{6}$ Walaupun hadits ini tidak mencapai derajat mutawatir, akan tetapi ijma' ulama telah menetapkan hal yang sama dengan hadits ini. ${ }^{7}$

Di dalam hadits lain diriwayatkan bahwa Rasulullah Saw. bersabda:

$$
\text { إن الله قد أعطى كل ذي حق حقه فلا وصية لوارث }
$$

“Sesungguhnya Allah Swt. telah memberikan kepada setiap yang punya hak akan haknya, maka tidak ada wasiat bagi ahli waris." ${ }^{\prime 8}$

${ }^{4}$ M. Quraish Syihab, Tafsir al-Mishbah; Pesan, Kesan dan Keserasian al-Quran, (Jakarta: Lentera Hati, 2000), Volume 2, hlm. 345.

${ }^{5}$ Ibnu Hajar al-'Asqalani, Fath al-Bari, (Beirut: Daar al-Fikr, t.t), Jilid 6, hlm. 12-13.

${ }^{6}$ Ibnu Hajar al-'Asqalani, Fath al-Bari, hlm. 19.

7 Muhammad bin Ismail al-Shan'ani, Bulugh al-Maram, (Beirut: Daar al-Fikr, t.t), jilid 3, hlm. 203.

${ }^{8}$ Ibnu Hajar al-'Asqalani, Fath al-Bari, hlm. 23. 
Hadits ini merupakan larangan berwasiat kepada ahli waris yang telah ditentukan pembagian warisannya. Hikmah dari larangan ini antara lain untuk menghilangkan kesan bahwa wasiat itu menunjukkan perbedaan kasih sayang antara sesama ahli waris yang pada akhirnya dapat menyebabkan perselisihan di antara mereka. Oleh sebab itu, maka seseorang tidak boleh berwasiat kepada ahli waris yang mendapat bagian warisannya, kecuali kalau diizinkan oleh ahli waris lainnya. Izin dari pihak ahli waris lain diperlukan karena harta yang telah diwariskan merupakan hak mereka bersama yang harus dibagi sesuai ketentuan syarak. Apabila mereka rela haknya dikurangi maka barulah wasiat tersebut dapat dilaksanakan. ${ }^{9}$ Akan tetapi, Syi'ah Zaidiyah, Syi'ah Imamiyah dan Syi'ah Ismailiyah berpendapat lain. Mereka berpendapat bahwa wasiat kepada ahli waris diperbolehkan walaupun tanpa ada izin dari ahli waris yang lain. Hal ini berdasarkan zahir surat al-Baqarah ayat 180 yang membicarakan tentang kewajiban berwasiat. Walaupun hukum wajibnya telah dinasakh, tetapi hukum kebolehannya masih tetap berlaku. ${ }^{10}$

Hadits ini diriwayatkan dengan banyak sanad, akan tetapi setiap sanad tidak terlepas dari perbincangan (maqal). Walaupun pada setiap sanad ada perbincangan, tapi dengan banyaknya sanad menunjukkan bahwa hadits ini mempunyai sumber (ashl). Bahkan Imam Syafi'i lebih cenderung mengatakan bahwa matan hadits ini adalah mutawatir. Tetapi al-Fakhr al-Razi menolak kemutawatirannya. ${ }^{11}$

Menurut jumhur ulama, ayat tentang waris dan hadits ini merupakan dalil yang menasakh pada ayat yang menyatakan tentang kewajiban berwasiat. Ada juga yang berpendapat bukan menasakh tetapi hanya mentakhshish atau menafsirkannya. ${ }^{12}$

Menurut para ulama mazhab Hanafi, dalil yang dzani tidak dapat mentakhshish apalagi menasakh dalil yang qath'i. ${ }^{13}$ Derajat dua hadits di atas adalah ahad, dan hadits ahad adalah dzani. Oleh karena itu, maka hadits tersebut tidak dapat mentakhshish ayat Alquran yang sifatnya qath'i. Dengan demikian, maka wasiat yang disebutkan dalam ayat Alquran tersebut dapat

${ }_{9}$ Wahbah al-Zuhaili, Al-Figh al-Islami wa Adillatuhu, hlm. 7475-7476.

${ }_{10}$ Wahbah al-Zuhaili, Al-Figh al-Islami wa Adillatuhu, hlm. 7477.

${ }^{11}$ Ibnu Hajar al-'Asqalani, Fath al-Bari, hlm. 24.

12 Wahbah al-Zuhaili, Al-Tafsir al-Munir, (Beirut: Daar al-Fikr, 2003), Jilid 2, hlm. 485-487.

${ }^{13}$ Wahbah al-Zuhaili, Ushul al-Figh al-Islami, (Beirut: Daar al-Fikr, 2004), Jilid 1, hlm. 252. 
dilakukan secara mutlak, dalam arti tidak dibatasi baik jumlah maupun objeknya.

\section{Tinjauan Filosofis Terhadap Pembagian Harta Waris dengan Wasiat}

Apabila hadits yang pertama dicermati, di sana ada ungkapan bahwa "meninggalkan ahli waris dalam keadaan kaya lebih baik daripada meninggalkan mereka dalam kondisi miskin sehingga menjadi beban bagi orang lain." Ungkapan ini menurut pendapat yang kuat adalah merupakan illat hukum dari pembatasan jumlah wasiat hanya sampai sepertiga. ${ }^{14}$ Jadi tujuan pembatasan jumlah wasiat untuk harta warisan adalah untuk menjaga agar ahli waris tidak menjadi beban bagi orang lain. Oleh karena itu, apabila wasiat dilakukan dengan pertimbangan kemaslahatan ${ }^{15}$ bagi kerabat (baik yang termasuk ahli waris maupun tidak) adalah telah sesuai dengan tujuan hadits tersebut walaupun wasiat itu untuk seluruh harta warisan.

Abu Zahrah mengungkapkan kenyataan bahwa sering anak-anak yang kematian ayahnya berada dalam kemiskinan, padahal mereka bukan ahli waris karena kebetulan sebagai cucu dari orang yang meninggal sehingga terhijab oleh saudara-saudara ayahnya yang hidup dalam kecukupan. Anak yatim tersebut menderita karena kehilangan ayah dan kehilangan hak kewarisan. Memang biasanya seseorang berwasiat untuk cucu yang yatim itu. Tetapi sering pula dia meninggal sebelum melakukannya. Atas dasar inilah maka undang-undang di Mesir mengambil alih aturan yang tidak dikenal di dalam mazhab yang empat, yaitu pemberian kepada cucu, dan hal ini menjadi pendapat para ulama yang lain.

Wilayah yang dicakup wasiat jauh lebih luas dari wilayah yang dicakup oleh waris. Wasiat adalah salah satu bentuk distribusi kekayaan yang dilakukan oleh seseorang setelah kematiannya untuk diberikan kepada pihak atau kepentingan tertentu dengan jumlah tertentu sesuai dengan keinginan dan pertimbangan pribadinya.

Dengan demikian, maka alternatif penentuan dalam pemberian wasiat terbuka luas. Ketentuan kepada siapa wasiat diberikan sepenuhnya menjadi

${ }^{14}$ Ibnu Hajar al-'Asqalani, Fath al-Bari, hlm. 19.

${ }_{15}$ Kemaslahatan di sini maksudnya adalah bahwa harta warisan tersebut dibagikan kepada kerabat sesuai dengan kondisi mereka walaupun mereka bukan ahli waris serta tidak sesuai dengan al-furudh al-muqaddarah. 
hak pewasiat. Dalam hal ini tidak ada batasan ataupun ketentuan yang ditetapkan oleh syariat kecuali standar ketaqwaan dan rasa takut kepada Allah Swt.. Dalam hal ini bisa saja pewasiat memberikan bagian yang lebih besar kepada anaknya yang cacat atau bahkan kepada anak angkatnya dari pada kepada anaknya yang sehat. Wasiat juga dapat menjangkau hal-hal yang tidak dapat dijangkau oleh ketentuan pembagian warisan. Sebagai contoh, bisa saja seseorang berwasiat untuk memberikan hak pemanfaatan rumah yang didiaminya selama ini kepada kedua orang tuanya seumur hidup atau diserahkan kepada siapa saja dari keluarganya yang dikehendakinya. Hal semacam ini tidak diatur dalam ayat-ayat waris, karena ayat-ayat waris hanya mengatur pembagian hak bagi anak-anak, pasangan suami istri, saudara dan kedua orang tua dengan persentase yang tetap tanpa mempertimbangkan kondisi material dan fisik mereka. ${ }^{16}$

Dalam Alquran, wasiat lebih diutamakan dari pada waris, karena ia berpotensi untuk mewujudkan keadilan yang khusus terkait dengan kepentingan pribadi dan memiliki efektivitas dalam pemanfataan harta, pengembangan relasi sosial dan hubungan kekeluargaan, di samping mencerminkan kepedulian orang yang berwasiat terhadap kepentingan pihak lain. Inilah yang dibuktikan dengan realitas objektif saat ini, bahwa setiap orang memiliki perhatian atau posisi khusus terhadap keluarga, orang-orang terdekat dan tingkat kepedulian terhadap pihak lain yang berbeda dengan orang lain.

Di samping itu, ketika ada seseorang yang meninggal dan tidak mempunyai ahli waris maka para ulama berbeda pendapat tentang kebolehannya untuk berwasiat dengan seluruh hartanya. ${ }^{17} \mathrm{Hal}$ ini juga lebih menguatkan pendapat bahwa wasiat dengan seluruh harta diperbolehkan.

Dari Alquran surat al-Nisa ayat 11 dan 12 dapat dipahami bahwa harta warisan dibagikan setelah seluruh wasiat dilaksanakan dan seluruh hutang dilunasi. Jadi dalam hal ini wasiat didahulukan dari al-furudh al-muqaddarah dalam waris. Dalam masalah harta, Islam juga memberikan keleluasaan kepada seseorang untuk mentasharrufkan harta sesuai dengan kehendak pemiliknya selama tidak bertentangan dengan ajaran Islam itu sendiri. Dan ketika seseorang meninggal, maka wasiat adalah landasan pertama

${ }^{16}$ Muhammad Shahrur, Metodologi Fiqih Islam Kontemporer, diterjemahkan oleh Sahiron Syamsuddin, MA dan Burhanudin, (Yogyakarta: Elsaq Press, 2004), hlm. 329.

17 Ibnu Hajar al-'Asqalani, Fath al-Bari, hlm. 19. 
pengalihan hak milik yang menduduki posisi utama di sisi Allah Swt. karena wasiat sangat mempertimbangkan berbagai syarat dan kondisi objektif yang secara spesifik melingkupi diri pewasiat. Wasiat juga mengimplementasikan keadilan spesifik pada tingkat pribadi. Allah Swt. menghormati keinginan dan kesenangan pribadi manusia dalam hal membagikan harta kekayaannya sesuai dengan kehendaknya. Allah hanya memberikan dorongan dan motivasi bagi orang yang berwasiat agar tidak melupakan pihak-pihak tertentu yang dipandang oleh Allah lebih baik jika diutamakan memperoleh wasiat, yaitu kedua orang tua, keluarga dekat, anak yatim, orang miskin dan anak-anak atau golongan ekonomi lemah.

Jadi, dengan demikian ayat waris dan ayat wasiat tidak dipahami sebagai pembuktian hukum yang hendak membatalkan atau menetapkan hukum syari'at pada seseorang, tetapi harus dipahami bahwa ayat-ayat tersebut sebagai salah satu bentuk aturan yang mengatur proses perpindahan harta kepemilikan, baik harta bergerak maupun yang tidak bergerak, dari seseorang kepada pihak lain yang namanya disebut dalam wasiat orang meninggal yang di dalamnya terdapat penjelasan bagian masing-masing penerima. Jika wasiat tidak ada, maka pembagian harta kepada pihak yang berhak didasarkan atas ketentuan dalam ayat-ayat Alquran yang membahas masalah kewarisan. ${ }^{18}$

\section{Penutup}

Dari pemaparan di atas dapat diambil kesimpulan antara lain: (1) Dalil-dalil yang menunjukkan tentang kewajiban berwasiat secara mutlak bersifat qathi, sedangkan dalil-dalil yang mentakhshishnya bersifat zanni, sehingga menurut ushul fiqh mazhab Hanafi, yang qath'i tersebut dapat dilaksanakan tanpa harus ditakhshish. Maka wasiat secara mutlak dapat dilaksanakan; (2) Tujuan dari pembatasan jumlah wasiat menurut hadits adalah untuk menjaga agar ahli waris tidak jatuh dalam kemiskinan. Dengan melihat kondisi objektif masing-masing individu, maka wasiat dapat dilaksanakan sesuai dengan kondisi objektif tersebut karena wasiat bersifat dinamis (dapat berubah) tidak seperti dalam waris yang jumlah bagian serta orang-orang yang berhak menerimanya sudah ditentukan; (3) Dalam melakukan wasiat, seseorang hendaknya memperhatikan prioritas orang-

${ }_{18}$ Muhammad Shahrur, Metodologi Fiqih Islam Kontemporer, hlm. 318-319. 
orang yang telah disebutkan oleh Allah Swt. yaitu kedua orang tua, kerabat, dan sebagainya, walaupun hal ini tidak bersifat wajib; dan (4) Jika tidak ada wasiat, maka pembagian harta orang yang meninggal didasarkan atas waris sebagaimana yang ada dalam Alquran dan Sunah.

\section{Pustaka Acuan}

al-'Asqalani, Ibnu Hajar, Fath al-Bari. Beirut: Daar al-Fikr, t.t.

al-Shan'ani, Muhammad bin Ismail, Bulugh al-Maram. Beirut: Daar al-Fikr, t.t.

Shahrur, Muhammad, Metodologi Fiqih Islam Kontemporer, diterjemahkan oleh Sahiron Syamsuddin, MA dan Burhanudin, (Yogyakarta: Elsaq Press, 2004),

Syihab, M. Quraish, Tafsir al-Mishbah; Pesan, Kesan dan Keserasian al-Quran. Jakarta: Lentera Hati, 2000.

Wahbah al-Zuhaili, Al-Figh al-Islami wa Adillatuhu. Beirut: Daar al-Fikr, 2004. Al-Tafsir al-Munir. Beirut: Daar al-Fikr, 2003. , Ushul al-Figh al-Islami. Beirut: Daar al-Fikr, 2004. 